Marquette University

e-Publications@Marquette

$1-1-2017$

\title{
Perception is Reality: Change Leadership and Work Engagement
}

Jay L. Caulfield

Marquette University, jay.caulfield@marquette.edu

Anthony Senger

Marquette University

Accepted version. Leadership \& Organization Development Journal, Vol. 38, No. 7 (2017): 927-945.

DOI. (C) 2017 Emerald. Used with permission. 


\section{ORGANIZATIONAL CHANGE AND WORK ENGAGEMENT: THE MEDIATING EFFECT OF LEADERSHIP}

Major organizational change has become the norm in today's globally competitive environment. Yet the benefits derived from its occurrence are many times elusive, resulting in decreased work engagement and work performance. Leadership has been identified as a critical factor in implementing and sustaining change and the change leadership literature clearly states specific leadership behaviors that are more prone to bring about positive change. Still, the statistics on successful major change are far from encouraging, and employee engagement during and following major change is often reported to decline. What we have not studied is how the alignment of employee perceptions of ideal leadership with perceptions of what leadership is actually occurring during change influences work engagement and, ultimately, change outcomes. This is an important consideration, however, in that employee perceived alignment is directly related to work engagement. Thus, the purpose of our study was to investigate whether employee perceived aligned leadership more fully explained the relationship between change and work engagement. Results supported our hypotheses in that leadership directly and indirectly influenced change through its effect on work engagement, implying that from an employee perspective, positive leadership is an integral link to both positive change and positive work engagement. 


\section{INTRODUCTION}

We live in a world of constant change. Proactive leaders continually assess the environment and enact changes that advantageously position their organizations to pursue opportunities and face challenges within local, regional and global communities. Similar to living organisms, those organizations able to creatively adapt and innovate are the ones likely to remain viable in the long run. Yet successfully planning, implementing and sustaining major organizational change, change that affects all major stakeholders to a certain degree, has had less than a stellar track record. For instance, the America Online/Time Warner Cable merger resulted in a loss in shareholder value of approximately $\$ 100$ billion (Duman, 2008; Gibbons, 2015; McGrath, 2015) and Boeing's 787 Dreamliner project, which had an estimated cost and development timeline of $\$ 6$ billion over four years instead resulted in a cost of $\$ 32$ billion over eight years (Ausick, 2014). As reported by Gibbons (2015), after a decade the UK government canceled its largest civilian IT project after spending $\$ 4$ billion on it. These examples and many more like them illustrate that failed change is costly and ubiquitous. Although there is disagreement in the literature regarding the percentage of failed change with the high end of the spectrum stated as $70 \%$ (Beer \& Nohria, 2001; Hughes, 2011) and the low end stated as 20\% (Weiner, Amick \& Lee, 2008), there is little disagreement that major change involves complex processes (Ford, 2008; Kotter \& Cohen, 2002; Resnicow \& Page, 2008), thereby making it more susceptible to failure when dynamic variables of influence remain unidentified or misunderstood.

Furthermore, the human welfare costs accompanying failed change (decreased work engagement, job insecurity, loss of work-life balance and increased stress) may be less quantifiable, but certainly just as concerning. Research results from Osterman (2000) indicate organizations that implement major organizational changes, including restructuring for greater 
profitability and quality, have higher layoffs in the long run and remaining employees are often uncompensated for any increases achieved in productivity or quality. According to Leana \& Rousseau (2000), poorly led change efforts lead to loss of internal and external customer relationships resulting in substantial social capital costs for employees, organizations and society as a whole. Analysts from Towers Watson (2015) report that employee engagement generally declines during major organizational change. Analysts from Aon Hewitt (2013) report in a white paper that employee engagement is a risk to manage, stating that it takes years for employee engagement to fully recover following major organizational change. As work engagement is a predictor of job performance (Bakker \& Bal, 2010; Salanova, Agut \& Peiró, 2005; Yalabik, Popaitoon, Chowne \& Rayton, 2013), having an engaged work force in today's globally competitive environment is clearly an organizational advantage.

Results from numerous studies suggest that the outcome of major change events is to a large degree dependent upon leadership behaviors (Battilana, Gilmartin, Sengul, Pache \& Alexander, 2010; Berson \& Avolio, 2004; Fiol, Harris \& House, 1999; Kotter \& Cohen, 2002; Mallinger, Goodwin \& O’Hara, 2009; Sirkin, Keenan \& Jackson, 2005). Effective change leadership enables followers to understand the need for change, and to become enthused about the opportunities that change brings to them, personally, and to the organization as a whole. However, few studies identify to what degree follower perceptions of leadership might influence work engagement and change outcomes. From a practical standpoint, these variable relationships are important as research indicates a direct relationship between employee engagement and work performance, indicating that ultimately followers' performance is a major determinant of whether organizational change becomes institutionalized (Mendes \& Stander, 2011; Ravichandran, Arasu \& Kumar, 2011; Vecina, Chacon, Sueiro \& Barron, 2011). Thus, the 
purpose of this study was to investigate how employee perceived alignment of ideal change and ideal leadership with that of perceived actual change and leadership influenced engagement.

\section{LITERATURE REVIEW AND HYPOTHESIS DEVELOPMENT}

\section{Change}

Change research identifies resistance to change as a significant barrier to successfully enacting and sustaining organizational change (Bateh, Castaneda \& Farah, 2013; Kotter \& Cohen, 2002). Major change is de-stabilizing causing any number of behavioral responses, including increased anxiety, fear of job loss and increased attrition. However, people have been shown to consistently embrace change when change is on their terms. One example is online banking. Twenty years ago most individuals did not engage in online banking. Now, according to the Pew Research Center, $51 \%$ of U. S. adults bank online and another $35 \%$ of those $51 \%$ bank using their mobile phones (Fox, 2013).

A second example is online shopping. In 2015, Mintel, a leading marketing intelligence agency, reported that $69 \%$ of Americans shop online at least monthly while $33 \%$ of those shop online every week. These examples are good indicators that individuals embrace change when they see the benefit of it. Generally, when change is communicated in a way that relates it to the vison and values of the organization, employees are more likely to see the benefit of the change. In her study of vanguard organizations going through change, Kanter (2008: 45) states, "Values turn out to be the key ingredient in the most vibrant and successful of today's multinationals. . . They offer people a basis of engagement for their work [emphasis added], a sense of membership and a stability in the midst of constant change." Finally, research indicates that when employees are included in the change process, they are more likely to engage in it (Heathfield, 2015; Kotter \& Kohen, 2002). 
In summary, when change is perceived as beneficial, vision and values driven and inclusive; it generates enthusiasm, motivation, innovation and creativity, which leads to healthy workplaces with engaged workers (DiFonzo, Bordia \& Rosnow, 1994; Elving, 2005; Gillespie \& Mann, 2004; Lewis, 1999; Sinek, 2009; Smelzer \& Zener, 1992). In these instances, employee perceptions of ideal change are closely aligned with their perceptions of the actual change occurring; we refer to this alignment as "employee perceived aligned change."

\section{Work Engagement}

As a construct in the psychological literature, work engagement tends to follow the current trend toward positive psychology, characterized by its focus on well-being, healthy living and optimal functioning. Maslach, Jackson and Leiter (1997) characterize work engagement as the antithesis of burnout, describing engaged workers as feeling energized, involved and selfconfident regarding the work that they perform while workers who face burnout are exhausted, cynical and experience reduced professional efficacy. Schaufeli, Salanova, Gonzalez-Roma \& Bakker (2002: 74) describe work engagement "as a positive, fulfilling, work-related state of mind that is characterized by vigor, dedication, and absorption. In their research, they describe vigor as possessing high levels of energy and mental resilience when working, thereby investing considerable effort and persistence in work despite road blocks. Dedication is characterized as being strongly involved with work, experiencing a sense of significance, enthusiasm, inspiration, pride and challenge. Finally, absorption is described as fully concentrating and happily engrossed with work, where time passes quickly and it is difficult to detach from work (Schaufeli, Bakker \& Salanova, 2006: 702). 


\section{Change and Work Engagement}

Analysts from Towers Watson (2015) conducted studies on the relationship between change and work engagement across 20 companies that were going through major transition and 27 companies that consistently performed well financially and were not in major transition. What they discovered when comparing the two groups is that those companies in major transition (undergoing major change such as mergers, acquisitions, major restructuring, forced changes in leadership), generally had lower employee opinions in those categories known to influence work engagement; specifically, communication, competitiveness, leadership and image, among others. However, results also indicated that positive leadership behaviors, such as those associated with transformational leaders and those identified in positive change processes, had a positive effect on work engagement during major organizational change. We also know from past research that individuals will embrace change when they understand the personal benefit of it and are included in its implementation (Kanter, 2008; Kotter \& Cohen, 2002; Sinek, 2009). These factors lead us to propose our initial hypothesis.

Hypothesis 1. Employee perceived aligned change is positively related to work engagement.

\section{Transformational Leadership}

The change leadership literature identifies transformational leadership behaviors as being most effective during change (Kotter and Cohen, 2002; Kegan \& Lahey, 2009; Sinek, 2009). Transformational leadership is a prominent leadership theory with an extensive body of research to support its tenets. Bass and Riggio (2006: 4) describe transformational leadership as "inspiring followers to commit to a shared vision and goals for an organization or unit, challenging them to be innovative problem solvers, and developing followers' leadership capacity via coaching, 
mentoring, and provision of both challenge and support. From a theoretical and research perspective, Bass' full range leadership model (Bass \& Riggio, 2006), which incorporates transformational, transactional and laissez-faire leadership styles, has the strongest theoretical support, has been researched extensively and is generally viewed favorably among change leadership scholars and practitioners. Its linkage to change is significant in that its core premise is based on transformation and change. Examples of leadership behaviors associated with transformational leadership include communication that focuses on a strong sense of purpose, behavior that fosters respect, confidence in goal achievement, inclusivity in problem solving, innovation that encourages learning, and investment in others' development.

A second conceptual framework is that of Tichy and Devanna (1986), who identify transformational leadership as highly effective in transforming organizations, which they state as being essential to organizational survival in today's dynamic environment. The model identifies three stages of transformation; specifically, recognizing the need for change, creating the vision and institutionalizing the change. These steps are somewhat analogous to Lewin's three stages of change; unfreezing, changing and refreezing (Burnes, 2004). Tichy and Devanna identify the importance of considering organizational culture during major change.

Thus, based on the research linking transformational leadership behaviors to positive change, we would expect that employees experiencing major organizational change would predominantly identify leadership behaviors associated with transformational leadership as ideal. We will refer to those instances where employee perceptions of ideal leadership behaviors are aligned with perceptions of actual leadership behavior occurring in the workplace as "employee perceived aligned leadership." In summary, the link between transformational leadership and 
change is quite evident within the change leadership literature. Based upon the strong linkage between change and leadership, we propose the following hypothesis.

Hypothesis 2. Employee perceived aligned change is positively related to employee perceived aligned leadership.

\section{Transformational Leadership and Work Engagement}

In past studies, transformational leadership behaviors have been found to be a significant predictor of work engagement (Ghadi and Fernando, 2013; Gözükara \& Simsek, 2015; Persson, 2010; Salanova, Lorente, Chambel \& Martínez, 2011; Tims, Bakker and Xanthopoulou, 2011; Zhu, Avolio and Walumbwa, 2009). In the Towers Watson (2015) study previously cited, employees identified leadership as the most significant driver of work engagement. Great change leaders were characterized by four attributes; specifically, they communicated vision in engaging ways, such as storytelling; they involved employees in modeling the future; they paid attention to barriers to change and addressed them promptly; and they fostered trust and confidence by authenticity and role modeling the way. Ghadi and Fernando (2013) demonstrated a direct and an indirect relationship of transformational leadership to work engagement with a partial mediating effect of meaning in work. Zhu, Avolio and Walumbwa (2009) found that follower characteristics moderated the relationship between transformational leadership and follower work engagement in that transformational leadership had more effect on work engagement when follower characteristics were more positive. Researchers have linked transformational leadership to nurses' extra-role performance through the mediating effect of transformational leadership (Salanova, Lorente, Chambel, \& Martínez, 2011). Researchers have also discovered that daily transformational leadership behaviors fostered employee work engagement (Tims, Bakker and Xanthopoulou, 2011). Gözükara \& Simsek (2015) linked transformational leadership to work 
engagement mediated by job autonomy. In a study by Persson (2010), satisfaction with leadership was a major predictor of work engagement. Thus, based on past research linking transformational leadership to work engagement, we propose the following hypothesis.

\section{Hypothesis 3. Employee perceived aligned leadership is positively related to work} engagement.

One of the primary purposes of mediation analysis is to investigate how an observed relationship between a predictor variable and an outcome variable occurs, which is considered an explanatory approach (MacKinnon, 2008). An important link between change, transformational leadership and work engagement is that of being "feelings" driven. Feelings are described as "mental associations and reactions to an emotion that are personal, acquired through experience (Meyer, 2012: para 1). During change transformational leaders inspire, challenge and develop followers through authentic, values-driven role modeling; thereby evoking feelings associated with trust and competency in attaining a shared vision and enhancing feelings associated with work engagement. Kotter and Cohen (2002: 1) emphasize the bond that exists between change and feeling as they write, "The single most important message in this book [The Heart of Change] is very simple. People change what they do less because they are given analysis that shifts their thinking than because they are shown a truth that influences their feelings." Kanter (2008) identifies shared values as the most important motivator in change environments. Sinek (2009: 41) further emphasizes this point as he writes, “People don't buy WHAT you do; they buy WHY you do it," implying the importance of clearly communicating an inspiring vision for why change is needed and how it will be of benefit, evoking feelings associated with motivation derived from shared values. Although emotions are fleeting, feelings may persist over a life time 
(Meyer, 2012), making them an important consideration when implementing major change as past feelings about change are likely to influence current perceptions of change.

Secondly, mediation analysis explores variables that past research identifies to have had significant relationships with an outcome variable, which is considered a design approach (MacKinnon, 2008). Based upon the multiple explanatory and design associations between change and leadership and the number of studies identifying significant relationships between change, leadership and work engagement, we propose our final hypothesis.

\section{Hypothesis 4. Employee perceived aligned leadership mediates the association}

between employee perceived aligned change and work engagement.

The research model is portrayed in Figure 1.

Insert Figure 1 about here.

\section{METHODS}

Employing a mixed methods design, we first examined qualitative data to better understand what types of changes and leadership behaviors employees perceived as being "ideal" during major organizational change. We then quantitatively explored the relationships between employee perceived aligned change, employee perceived aligned leadership and work engagement.

Based on simplicity of recruitment and desired organizational diversity in sample, we employed an anonymous, non-probability, purposive snowball method of sampling, using social media networking to initiate the snowball. Age verification and consent were built into the survey with mandatory affirmative responses required to participate. In order to ensure the anonymity of the respondents, survey security features were activated, thereby collecting survey 
responses without reporting email or IP addresses. To be included in the sample, participants had to have reported experiencing a major change during the past 24 months within the organization they were currently employed. We collected 105 complete and usable survey responses over a 30-day period.

\section{Demographic and Organizational Data Summary}

In past studies exploring work engagement, the demographic variables of age and gender were significantly related to work engagement in that older employees showed higher levels of work engagement (Simpson, 2009; Pitt-Catsouphes \& Matz-Costa, 2008; Schaufeli \& Bakker, 2004). Results of gender on differences in work engagement vary. One study found men more engaged than women (Schaufeli \& Bakker, 2004) while other studies have shown no gender differences in work engagement (Korunka, Kubicek, Schaufeli \& Hoonakker, 2009; Persson, 2010). Participants from this study $(n=105)$ reported the following demographical data. Sixtyone percent (61\%) were male. Age range of participants was 26 - $30(6.1 \%) ; 31-35(8.8 \%) 36-$ $40(30.8 \%), 41-45$ (20.2\%), $46-50(11.5 \%) ; 51-55$ (10.6\%); $56-60$ (7.0\%); $61-65(2.6 \%)$ and 66 - 70 (less than 1\%). All worked for organizations within the United States. Nearly 39\% reported having earned a graduate degree, over $20 \%$ reported having completed some graduate work, another $25 \%$ reported earning a Bachelor's degree and over $12 \%$ reported earning a terminal degree, making this a highly educated group when compared to 2015 reports filed by the United States Census Bureau.

(www.census.gov/hhes/socdemo/education/data/cps/2015/tables.html)

In addition to demographical data, data was collected on several organizational variables. Past studies demonstrated that managerial status (Schaufeli and Bakker, 2004) and organizational size (Kahn, Rehman \& Fatima, 2009) were significantly related to work engagement; the 
relationship between managerial status and work engagement was positive while the relationship between organizational size and work engagement was negative. Thus, we collected data on these variables as well as a few others we considered pertinent to this study. Participants reported the type of organization they worked for during the major change (69\% for-profit, $12 \%$ nonprofit, $6 \%$ governmental and remaining $13 \%$ religious or social). The average tenure with the organization was reported as ten years, and the time that had passed since the major change event occurred was reported as nine months with no one reporting more than 24 months. Total number of individuals employed by the organization was as follows: $25 \%$ reported up to 100 employees, $24 \%$ reported up to 500 employees, $21 \%$ reported up to 1,000 employees, $13 \%$ reported up to 5,000 employees and 18\% reported over 5,000 employees. Forty-two percent (42\%) reported supervising employees at some level and the number of organizational layers between the participant and the primary change agent was reported as follows: $22 \%$ reported one layer, $37 \%$ reported two layers, $14 \%$ reported three layers, $15 \%$ reported four layers and the remaining $12 \%$ reported over five layers.

\section{Qualitative Measures}

We collected qualitative data for the purposes of determining to what degree participant responses aligned with what past research reports regarding change and leadership conditions, with the intent of adding credibility to research results, identified by Klenke (2008) as a primary reason to propose a mixed methods design. MacKinnon (2008) also identifies qualitative data as being an important component for explanatory mediation analysis. We also wanted to compare our qualitative analysis with our quantitative analysis to determine whether there was consistency between the two analyses (Klenke, 2008; MacKinnon, 2008). Finally, the qualitative data aided participants in reflecting upon the alignment of what they perceived as ideal changes 
and ideal leadership behaviors, and what they perceived as actual changes and actual leadership behaviors occurring during the major organizational change.

First, participants were asked to reflect upon the major organizational change that they had experienced. Examples of major changes included forced changes in leadership, mergers, acquisitions, new product lines and geographical re-location. They were then instructed as follows, "Around the time of the major organizational change that you have in mind, list the top three things you believe your organization really needed to change. These three things are your ideal changes for the organization. In other words, these are the things that you felt your organization really needed to change if you had been in charge." Secondly, in the same manner, participants were asked to list the top three ideal leadership behaviors during the change. Again, the intent was to encourage reflection on the concepts before moving to a quantitative ranking of the alignment of perceived ideal change with perceived actual change and the alignment of perceived ideal leadership with perceived actual leadership.

\section{Quantitative Measures}

Predictor variables. Upon review of measures for personal alignment with a target, past observational studies in organizational research have employed Venn diagram scales (Bergami \& Bergozi, 2000; Shamir \& Kark, 2004; Van Quaquebeke, Kerschreiter, Buxton \& van Dick, 2010). Bergami and Bergozi used a Venn diagram scale to measure the alignment between employee perceived self-definition and organizational identity. Shamir and Kark used a Venn diagram scale to measure alignment between employee perceived identity with the organizational unit in which they were employed and Van Quaquebeke et al. employed a Venn diagram scale to measure the alignment between employee perceived leader and follower values. As we were interested in measuring alignment with a target (ideal change and ideal leadership), 
we used one Venn diagram scale to measure employee perceived alignment with change and a second Venn diagram scale to measure employee perceived alignment with leadership. We used these self-reported measures based on the nature of the constructs. Past methodologists and researchers substantiate the use of self-reporting measures as being appropriate for private events (Chan, 2009; Conway and Lance, 2010; Judge, Bono \& Locke, 2000). We were measuring employee perceptions; thus, self-reporting was an appropriate method of measurement.

Several steps were taken to clarify the use of the Venn diagram scale and to focus participants on the definition of the predictor and mediator variables being measured. As mentioned, we first asked participants to list three ideal changes and three ideal leadership behaviors that they believed needed to occur during the major organizational change they were thinking about. They were then told that the changes and leadership behaviors they identified were not intended to limit their comparisons, as it was likely that there were more than three ideal changes and ideal leadership behaviors that they could identify. We instructed them to make the comparison considering as many factors as came to their attention versus just the top three they had listed. Finally, we gave an example of a somewhat humorous scenario of what might be perceived as a good night's sleep, applying the Venn diagram scale to illustrate alignment and misalignment of that perception.

To further illustrate, refer to Figure 2. The upper row of circles represents an employee's perception of ideal changes while the lower row of circles represents an employee's perceived observed or actual changes. Participants were instructed to select a numerical point on the scale that best represented their alignment to the target concept (ideal changes) with " 7 " indicating total alignment and " 1 " indicating total misalignment; the score reported measured employee 
perceived aligned change. Precisely, the same procedure was used to measure employee perceived aligned leadership.

Insert Figure 2 about here.

Outcome variable. We selected work engagement as the outcome variable. Although work engagement may fluctuate somewhat during major change, it is reported as a relatively stable construct that does not show significant fluctuation over a two-year period following major change (Aon Hewitt, 2013; Mauno, Kinnunen \& Ruokolainen, 2007). This is an important consideration to this study for three reasons. Firstly, it helps in identifying the time period following major organizational change that work engagement is likely to remain stable. Secondly, as work engagement has a direct relationship with work performance (Bakker \& Bal, 2010; Salanova et al., 2005; Yalabik et al., 2013), engagement is a worthwhile construct to measure during major organizational change. Thirdly, if work engagement declines due to organizational change, it is likely that it will remain in that declined state for a few years following the change, which implies that maintaining work engagement at the same level throughout major change is important to work performance not only during the change, but for a few years following the change.

We chose the Utrecht Work Engagement Scale as the measure for the outcome variable, work engagement. Derived from the earlier work engagement research of Shaufeli, Salanova, González-romá and Bakker (2002), the three constructs measured in the Utrecht scale are vigor, dedication and absorption. The long form of the scale, UWES-17, was built into the web-based survey. Sample statements from the UWES-17 include: "At my work I feel bursting with energy" (vigor); "I am enthusiastic about my job" (dedication); and "Time flies when I am 
working" (absorption) (Schaufeli \& Bakker, 2004). The UWES-17 scale has a reported internal reliability, Chronbach's $\alpha$, of 0.93 and has demonstrated test-retest reliability, stability coefficient $\mathrm{r}_{\mathrm{t}}$, ranging from 0.63 to 0.72 (Schaufeli and Baker, 2004). Researchers conducted a study investigating the validity of the Utrecht Work Engagement Scale, reporting findings that work engagement appears to be a highly stable indicator of employee well-being (Seppälä et al., 2008). Following completion of the Venn diagram scales, participants completed the 7-point work engagement scale.

\section{RESULTS OF QUALITATIVE ANALYSIS}

Upon review of the qualitative data, we recognized that many of the leadership behaviors and change actions identified by participants focused on values. From previous studies, we also knew that transformational leadership behaviors are often values-driven (Avolio \& Gardner, 2005; Brown \& Treviño, 2006; Copeland, 2014), and that change leadership behaviors were mostly associated with transformational leadership. Therefore, we employed values coding to the qualitative data. Saldaña (2013) defines values coding as, "The application of codes to qualitative data that reflect a participant's values, attitudes, and beliefs, representing his or her perspectives or worldview" (p. 268). After coding the data, we performed a thematic analysis, which originated from the two coded data sets, specifically ideal changes and ideal leadership behaviors. Discussed in order of frequency (high to low) of coded items attributed to a theme, these themes represent the values identified in the qualitative dataset.

\section{Change Themes}

Communication. According to past studies (DiFonzo et al., 1994; Elving, 2005; Lewis, 1999; Sinek, 2009; Smelzer and Zener, 1992), frequent communication from leadership throughout the change process is vital to effective change. Participant responses described the 
quality of communication more frequently than any other change action. Major change events often generate chaos and uncertainty, which increases resistance to change (Elving, 2005). Communication is a major tool that has the potential to decrease that resistance. Primarily participants identified that they wanted to know why the change was needed, what the plan for change entailed and how their jobs would be affected.

Planning. It is interesting to note that although many articles state that planning for change is important, there is little research regarding planning specific to change. In fact, when referring to planning during change, Kotter and Cohen (2002) observed, "Strategic plans motivate few people, but a compelling vision can appeal to the heart and motivate anyone" (p. 69). Yet participants in this study identified planning as being very important to effective change. According to participant responses, good planning during major change included: devoting time to focus on the planning process, involving employees most impacted by the change in the planning process, active listening at all levels of the organization during planning meetings, including in the plan needed training to implement the change actions and ensuring that change actions occurring as a result of the change were aligned with the mission, vision and values of the organization.

Values-driven change. Many participants spoke to the importance of linking the change to the espoused values of the organization. Examples included "trust our peers," "commitment," "pride in doing good work," "inclusivity at all levels," "innovation," "customer focus," and "treat people with respect." As previously noted, Kanter (2008: 45) states, "Values turn out to be the key ingredient in the most vibrant and successful of today's multinationals. . They offer people a basis of engagement for their work, a sense of membership and a stability in the midst of constant change." 
Inclusivity. Whereas participant phrases regarding inclusion as an ideal leadership behavior were focused on valuing all employees, inclusivity as a change action focused on including employees most impacted by the change actions taking place. Participants addressed inclusivity in phrases such as "avoid top down process," "reach out more to individuals who are not engaging or understanding the changes" and "feedback from the primary members involved." Miller (1998) defines inclusion during a change process as identifying which individuals are permitted to participate and contribute. Barriers to inclusion may be subtle or more tangible. Regardless, perceptions of exclusion result in failure to gain commitment and contributions from those feeling excluded (1998).

Quality and training. According to Strebel (1996), employees need to be part of redefining what they need to do to maintain the quality of services and products, or companies will be unsuccessful in meeting objectives of major change. Examples of participant responses as related to quality of products and services included "use our people and skills to achieve better product," "deliver products that resonate well with customers" and "maintain one of the best product validation teams in the US." According to Uma (2013), employee training improves morale and increases productivity and performance, which surpasses the costs associated with training. However, some employees find training and development for new job roles nearly as threatening as job loss (Pardey, 2007). Thus, addressing the fear of failure early in the training process may help employees focus on learning the new skills required of them.

\section{Leadership Themes}

Inspiring communicator. Leadership communication has been identified as a key mechanism of influence for change-oriented leaders (TowersWatson, 2015; Seyranian, 2014). Participant phrases describing communication included, "share the vision through extraordinary 
communication skills," "communicate the reasons for change," and "honest and open communication frequently." These behaviors are often associated with transformational leaders. In a longitudinal study across six continents over a 25-year period identifying characteristics most admired in leaders, inspiring ranked fourth on the list for each of the five-year points of data collection, receiving over $60 \%$ of the votes four out of five times (Kouzes \& Posner, 2012).

Honesty and competency. In the same study previously cited, honesty and competency were in the top three characteristics identified as most admired in a leader, receiving over $60 \%$ of votes for each five-year point in which data was collected (Kouzes \& Posner, 2012). Participant responses in these areas included, "Be honest," "Tell the truth," "Integrity," "Honesty," "Truthful," "Competent in change," "Excellent skills," "Resourceful" and "Think out of the box."

Inclusivity. Gen Y, the largest participant age group in this study (estimated at 50\%), is reported to especially value inclusion in the work place (Kane, 2015), which may be a factor contributing to its thematic identification in both the change and leadership categories. In a recent study, 24 CEOs of companies and divisions known for practicing diversity and inclusion were interviewed; results indicated that a culture of inclusion is values-driven more than strategy-driven (Groysberg \& Connelly, 2013), supporting the importance of values-driven leadership. Examples of participant phrases describing inclusion were "value all employees," "communicate with all stakeholders" and "get buy-in from the whole company."

Respect. In a study involving nearly 20,000 participants (Porath, 2014), employees who believed that their leaders respected them reported being 55\% more engaged on the job. In this same study, respect had more of an influence on engagement than any other outcome measured, including recognition and appreciation; communicating an inspiring vision; and providing useful 
feedback. Participant responses indicated that leaders should not only respect them, but also behave in ways that earn respect from them.

Decision-making. During major change, decisions occur in a turbulent and unstable environment, making the quality of decision-making even more critical than in a time of stability. Decision-making is considered a critical skill for successful leaders to possess (Kase, 2010; Vroom, 2000). Leaders who possess the ability to balance emotion with reason when making decisions are more likely to make positive decisions for important stakeholders (Kase, 2010). Responses included "able to make tough decisions" and "competent decision-maker."

In summary, the thematic analysis aligned with the change leadership literature. Participant perceived ideal changes and ideal leadership predominantly focused on values that have been identified and supported as important to employees during organizational change.

\section{RESULTS OF QUANTITATIVE ANALYSIS}

As an overview, we employed partial correlation to explore the relationships between predictor and outcome variables and associated covariates. We then used regression and hierarchical regression analysis to determine whether our data met the four assumptions identified as necessary for mediation to occur (Barron and Kenny, 1986). To test our final hypothesis, as recommended by several mediation methodologists (Hayes, 2013; Jose, 2013; Preacher \& Hayes, 2008), we used AMOS with its bootstrapping feature to conduct a basic mediation analysis. Finally, we checked for an interaction effect.

Table 1 displays the means, standard deviations and intercorrelations among the main variables and the covariates in the study. Note that the mean scores for the three main variables, specifically employee perceived aligned change, employee perceived aligned leadership and work engagement are near the midpoint of the 7-point measurement scales, indicating that on 
average, participants reported less than ideal scores for all of these variables. The statistically significant positive correlational relationships between the main variables are initial indicators in support of the mediation model.

Covariates were selected based on past associations reported in the literature. A statistically significant gender difference existed in the number of reported layers between the change agent and the employee, specifically women reported less layers then men. This reported difference could at least partially explain the significant gender difference in work engagement with women reporting higher engagement. The same statistically significant correlational difference existed with the number of layers between change agents and employees overall, in that those reporting less layers also reported higher levels of work engagement. Employees in smaller organizations (size measured by number of employees) reported being more engaged than those in larger organizations, in support of previous research findings (Kahn, Rehman \& Fatima, 2009); larger organizations reported significantly more layers between change agents and employees.

A positive correlation existed between reported level of education and work engagement. Past findings report positive relationships between work engagement and autonomy (Gözükara \& Simsek, 2015), which generally occurs in jobs requiring more education. A negative relationship existed between the number of layers reported and the level of education, supporting the notion that more highly educated individuals are generally in positions closer to the top of the organizational chart. Finally, the insignificant relationship between time passed and work engagement supports past research implying that work engagement levels are fairly stable over long periods of time (Aon Hewitt, 2013).

Insert Table 1 about here. 
Next we ran a hierarchical regression controlling for associated covariates to determine if employee perceived aligned change was positively related to work engagement and if the addition of employee perceived aligned leadership further explained the influence of employee perceived aligned change on work engagement. Results of the hierarchical regression analysis are reported in Table 2, confirming Hypotheses 1 and 3 and meeting Steps 1 and 3 for mediation (Baron \& Kenny, 1986), specifically the predictor variable is significantly related to the outcome variable and the mediator is also significantly related to the outcome variable.

Linearity was evident by assessing partial regression plots and a plot of studentized residuals against predicted values. The Durbin-Watson statistic of 2.035 indicated independence of residuals. Homoscedasticity was assessed by visual inspection of a plot of studentized residuals versus unstandardized predicted values. Multicollinearity was not evident as tolerance values ranged from .728 to .997 . Studentized deleted residuals were not greater than $+/-3$ standard deviations, no leverage values were less than 0.2 nor were values for Cook's distance above 1 . The assumption of normality was met as assessed by visualizing a Q-Q plot.

Insert Table 2 about here.

We then conducted a linear regression analysis to test Hypothesis 2. Regression results indicated a significantly positive relationship between employee perceived aligned change and employee perceived aligned leadership, $F(1,104)=32.654, p<.001, R^{2}=23.3 \%$ supporting Hypothesis 2 and Baron and Kenny's (1986) Step 2, specifically that the predictor variable is significantly related to the mediator.

Boot strapping is reported to be particularly effective with small sample sizes, which was the case in this study (Jose, 2013). Thus, to test Hypothesis 4 and Baron and Kenny’s (1986) Step 4, 
we conducted a basic mediation analysis in AMOS using bootstrapping $(n=5,000)$ and biascorrected confidence intervals. Please refer to Figure 3 to view the AMOS fully saturated model.

Insert Figure 3 about here.

With the exception of Hoelter's critical N, AMOS reported model fit indices indicated a fairly good fit. However, based on the work of Jose (2013), who states that in basic mediation models where the direct relationship between the predictor variable and the outcome variable is reduced to insignificance by mediation, as is the case with this model, pruning the model by deleting the direct path, which results in one degree of freedom versus a fully saturated model, may lead to a better fitting model as the degree of freedom permits model fit indices to be estimated (p. 104). Thus, the direct path was pruned (Figure 4), which improved Hoelter's critical N substantially and also improved the root mean square error of approximation (RMSEA). AMOS reported the following fit indices for the pruned model: goodness of fit $(\mathrm{GFI})=1.00$; RMSEA of less than .001 as compared to 0.406 previously; comparative fit index $(\mathrm{CFI})=1$; relative fit index $(\mathrm{RFI})=$ .99 , Hoelter's Critical $\mathrm{N}=23,958$ as compared to 15 previously, standardized root mean residual $(\mathrm{sRMR})=0.0040$ and adjusted goodness of fit index $(\mathrm{AGFI})=.99$. It should be noted that the size of the indirect path $(a b)$ as reported by AMOS changed slightly from 0.224 in the saturated model to 0.230 in the pruned model. According to Jose (2013), this only occurs when the mediated ć path has been reduced to nearly zero (p. 106). Figure 4 illustrates the pruned model.

Insert Figure 4 about here.

MacKinnon (2008) recommends calculating asymmetrical confidence intervals if the indirect effect has been calculated as $a^{*} b$, which was the case in this study. Thus, asymmetrical 
confidence intervals are reported using asymmetrical confidence limit values of 1.6175 (lower confidence limit) and 2.2540 (upper confidence limit) (MacKinnon, 2008, p. 97). The size of the standardized indirect effect, 0.230 (standard error $=.054)$ was statistically significant, $95 \% \mathrm{CI}=$ $0.142-0.352, p<.001$, supporting Hypothesis 4 as well as Baron and Kenny's (1986) fourth criterion whereby the relationship between employee perceived aligned change and work engagement was mediated by employee perceived aligned leadership. According to Kenny (2015), the effect size of a boot strapped model may be estimated by dividing the indirect effect $(a b)$ by the total effect $(c)$ when the standardized $c$ is at least $+/-0.20$. If the effect size is greater than 0.80 , full mediation has occurred. Kenny further states that this measure is informative when ć is statistically insignificant, as is the case in this model. As stated previously, standardized $c$ was reported as .230. Thus, $a b / c$ was applied to estimate effect size, which is reported as 0.98 .

According to MacKinnon (2008, p. 61), for basic mediation models, it is important to check for an interaction effect between the predictor variable and the mediator, which when statistically significant would indicate that the outcome variable differs across different levels of the predictor variable. Thus, we tested for an interaction effect and results were statistically insignificant $(p=.23)$, indicating no moderation effect.

\section{DISCUSSION}

Drawing from the change leadership literature, the purpose of our study was to investigate whether alignment of employee perceptions of ideal change and leadership with perceptions of actual change and leadership influence work engagement. To explore the relationship between the main variables, we employed a basic mediation model. Our four hypotheses mirrored Baron and Kenny's four steps needed to claim mediation. All hypotheses were supported implying that leadership indirectly and fully mediated change through its effect on work engagement. 


\section{Contributions and Theoretical Implications}

This study contributes to the existing change leadership literature in four ways. First, thematic analysis of the qualitative data indicates that participants' identification of what they perceive as ideal change actions and ideal leadership behaviors during major change are, for the most part, supported by the change leadership literature. An exception is that the participants identified planning for major change as being important, which has not been particularly abundant in the change leadership literature, but has instead been more prevalent in the change management literature (Rafferty \& Simons, 2006; Jones, Chonko, Rangarajan \& Roberts, 2007; Weiner, Amick \& Lee, 2008).

Secondly, as employee perceived aligned leadership fully mediated the relationship between change and work engagement, the importance of leaders' awareness of how their actions might either positively or negatively influence work engagement throughout and following the change process is accentuated.

Thirdly, although the leadership behaviors identified as ideal during major change are predominantly associated with transformational leadership, some of the themes identified suggest application of additional leadership theories. For example, the inclusivity theme appearing in both the change and leadership categories might be applied to distributive leadership in that inclusivity encourages looking beyond formal leaders' behaviors and instead focusing on how individuals within an organization might become informal leaders as related to tasks that rely on their expertise, experience and competency (Brown \& Gioia, 2002; Pearce \& Conger, 2002). Authentic leadership applies to the integrity and honesty leadership theme in that authentic leaders are morally regulated internally and transparent in their values and in sharing of information (Avolio and Gardner, 2005; Covey, 1989; Skei, 2014). Skjei describes authentic leaders as those who display consistent character that is values based. Authentic leaders are 
transparent, trustworthy, noted for their integrity and are comfortable with ambiguity. These consistently demonstrated leadership behaviors help employees understand what to expect from leadership, leveraging the instability that generally occurs during major change. Such authentic behaviors were identified frequently as ideal by participants in this study, making authentic leadership theory especially applicable during change.

Finally, due to the dynamic nature of the environment and the change process itself, components of complexity theory of leadership (CLT) apply. CLT as described by Uhl-Bien, Marion and McKelvey (2007) takes advantage of dynamic environments by exploring strategies that are collaborative and creative within an organizational context that supports and enables learning. An example of a firm that applies CLT is Google (He, 2013). Google has what it terms "FixIts" where all Google staff stop what they are doing and focus $100 \%$ of their energies on solving a specific problem together. "Google Cafés" provide a venue for bouncing ideas off other Googlers. "Googlegeist" is a survey that aggregates employee feedback facilitating identification of "FixIts" to solve major problems. These three strategies generate rapid response of sharing and building upon ideas, providing excellent examples of how learning organizations operate and compete in a dynamic global environment where change has become the norm.

\section{Practical Implications}

In several instances, participants highlighted the importance of having stabilizing factors in the face of significant change. As an example, participants stated that the vision and values of the organization should not change and several others said they did not want the organizational culture to change. Others mentioned that they did not want their team or supervisor to change. Individuals who successfully lead and participate in major change seem to possess the wisdom to recognize the paradox of change, where chaos and complexity are grounded in stability. Wharton 
(2015: para 2) describes this paradox as one of "unstable conditions but with underlying, integrating order." Mustafa, Shaikh and Haroon (2012: 1) tell us that "chaos and order are not enemies, only opposites" and that they are often "two critical aspects of the same underlying truth." The vision and values of the organization, when well-crafted and visible in thought, word and action, appear to provide the stability needed to align employees with the chaos and complexity of changes occurring. Supportive relationships with supervisors and team members also play a stabilizing role as does authentic leadership. Thus, the organization's vison and values, which serve as its guidance system, should be interwoven with change, and it is primarily the job of leadership to make certain that happens, and to behave in ways that authentically mirror that guidance system. Leadership throughout the organization also should understand the need to leverage chaos with these stabilizing features. As expressed in the words of Terri Kelly, CEO of W. L. Gore and Associates, in a recent interview:

But then we have almost rules of engagement. There's a lot of work that goes into establishing our core values, what are our principles, how are we going to make decisions. And so the role of the leader is really to make sure that they are every day creating that framework for associates, helping them understand the boundaries, so that they can operate and be empowered. Because if you don't do that, it truly just becomes chaos. [Emphasis added.] (Young \& Hobson, 2015: para 8)

Assessing the organization's knowledge of and commitment to the guidance system while also assessing how individuals perceive the chaos of change prior to enacting major change will likely improve change outcomes. An analysis of successful and failed change events may 
provide further insights regarding how certain leadership behaviors and changes might better maintain the delicate balance between stability and chaos.

\section{Limitations and Future Directions}

There are several limitations in this study. All study participants were anonymous, which meant we knew little details regarding the organization, the leaders, the participants themselves and the particular major change that participants were referring to when identifying perceived change actions and perceived leadership behaviors, nor could we insure that participant responses indicated a true understanding of the constructs being studying. Furthermore, the survey captured data at one point in time. Clearly a longitudinal study might provide additional insights regarding the change process, itself, as well as the relationship between change, leadership and work engagement.

Secondly, all participants were recruited using social media. Clearly there are a number of advantages in online data collection, with the predominant ones being cost and efficiency. On the other hand, online surveys include biases inherent in the data collection process by excluding those who are unfamiliar with online surveys or have limited access to the internet. Also, response rates cannot be calculated. Recruiting participants directly from a number of organizations going through major change as well as from organizations that are stable would provide a stronger research design.

Thirdly, although participants identified what they perceived as three ideal changes and three ideal leadership behaviors during major change, we do not know what additional factors they considered when assessing the alignment between perceived ideal changes and leadership behaviors and perceived actual changes and leadership behaviors occurring. Having that information could be of benefit. Although leadership fully 
mediated the relationship between change and work engagement, it accounted for approximately one-quarter of the variance in the hierarchical regression model, leaving ample room for additional mediators to be identified. Finally, as non-probability sampling was used, generalization is limited.

Although major organizational change has become the norm in today's globally competitive environment, its benefits are not often fully realized. For several decades, leadership has been identified as integral to successful change. Results supported our hypotheses in that leadership directly and indirectly influenced change through its effect on work engagement, implying that from an employee perspective, positive leadership is an integral link to both positive change and positive work engagement.

\section{REFERENCES}

Aon Hewitt. Managing employee engagement during times of change. Retrieved from http://www.aon.com/attachments/human-capitalconsulting/2013_Managing_Engagement_During_Times_of_Change_White_Paper.pdf, June, 2013.

Avolio, B. \& Gardner, W. 2005. Authentic leadership development: Getting to the root of positive forms of leadership. The Leadership Quarterly, 16(3): 315-338.

Ausick, Paul. Why a Boeing 787-9 Dreamliner Costs $\$ 250$ Million. Retrieved from http://247wallst.com/aerospace-defense/2014/06/17/why-a-boeing-787-9-dreamliner-costs250-million/ June 17, 2014.

Bass, B. \& Riggio, R. 2006. Transformational leadership, Mahwah, N.J.: Lawrence Erlbaum Associates, Publishers.

Bakker, A. B. \& Bal, M. P. 2010. Weekly work engagement and performance: A study among starting teachers. Journal of Occupational and Organizational Psychology, 83(1): 189-206.

Baron, R. M. \& Kenny, D. A. 1986. The moderator-mediator variable distinction in social psychological research: Conceptual, strategic, and statistical considerations. Journal of Personality and Social Psychology, 51(6): 1173-1182.

Bateh, J., Castaneda, J. \& Farah, J. E. (2013). Employee resistance to change. International Journal of Management and Information Systems, 17(2): 113-116. 
Battilana, J., Gilmartin, M., Sengul, M., Pache, A. \& Alexander, J. 2010. Leadership competencies for implementing planned organizational change. The Leadership Quarterly, 21(3): $422-438$.

Bergami, M. \& Bagozzi, R. P. 2000. Self-categorization, affective commitment and group selfesteem as distinct aspects of social identity in the organization. The British Journal of Social Psychology, 39(4): 555-77.

Beer, M. \& Nohria, N. 2000. Cracking the code of change. Harvard Business Review, 78(3): $133-141$.

Berson, Y. \& Avolio, B. J. 2004. Transformational leadership and the dissemination of organizational goals. A case study of a telecommunication firm. The Leadership Quarterly, 15(5): 625-646.

Brown, M. E. \& Gioia, D. 2002. Making things click-distributive leadership in an online division of an offline organization. The Leadership Quarterly, 13(4): 397-419.

Brown, M. \& Treviño, L. 2006. Ethical leadership: A review and future directions. The Leadership Quarterly, 17(3): 595-616.

Burns, B. 2004. Kurt Lewin and the planned approach to change: A re-appraisal. Journal of Management Studies, 41(6): 977-1002.

Chan, D., 2009. So why ask me? Are self-report data really that bad? In C. E. Lance and R. J. Vandenberg (Eds.), Statistical and methodological myths and urban legends: Doctrine, verity and fable in the organizational and social sciences: 309-332. New York: Routledge.

Covey, S. R. (1989). The 7 habits of highly effective people. New York: Simon \& Schuster.

Pearce, C. L. \& Conger, J. A. 2002. Shared leadership: Reframing the hows and whys of leadership. Thousand Oaks, CA: Sage Publications.

Conway, J. M. \& Lance, C. E. 2010. What reviewers should expect from authors regarding common method bias in organizational research. The Journal of Business and Psychology, 25(3): $325-334$.

Copeland, M. 2014. The emerging significance of values based leadership: A literature review. The International Journal of Leadership Studies, 8(2): 105-135.

DiFonzo, N., Bordia, P. \& Rosnow, R.L. 1994. Reining in rumors. Organisational Dynamics, 23(1): 47-62. 
Duman, Marv. Biggest merger and acquisition disasters. Retrieved from http://www.investopedia.com/articles/financial-theory/08/merger-acquisition-disasters.asp June 17, 2008.

Educational attainment. Retrieved from http://www.census.gov/hhes/socdemo/education/data/cps/2014/tables.html, 2014.

Elving, W. J. L. 2005. The role of communication in organisational change. Corporate Communications: An International Journal, 10(2): 129-138.

Fiol, C. M., Harris, D. \& House, R. 1999. Charismatic leadership: Strategies for effecting social change. The Leadership Quarterly, 10(3): 449-482.

Ford, R. 2008. Complex adaptive systems and improvisation theory: Toward framing a model to enable continuous change. Journal of Change Management, 8(3-4): 173-198.

Fox, S. 51\% of U.S. adults bank online. Retrieved from http://www.pewinternet.org/2013/08/07/51-of-u-s-adults-bank-online/, August 7, 2013.

Ghadi, M. Y., Fernando, M. \& Caputi, P. 2013. Transformational leadership and work engagement: the mediating effect of meaning in work. Leadership and Organization Development Journal, 34(6): 1-34.

Gibbons, P. 2015. The science of successful organizational change: How leaders set strategy, change behavior, and create an agile culture. United States: Pearson Education.

Gillespie, N. A. \& Mann, L. 2004. Transformational leadership and shared values: The building blocks of trust. Journal of Managerial Psychology, 19(6): 588 - 607.

Gözükara, I. \& Simsek, O. F. 2015. Linking transformational leadership to work engagement and the mediator effect of job autonomy: A study in a Turkish private non-profit university. Social and Behavioral Sciences, 195(3): 963-971.

Groysberg, B. \& Connolly, K. 2013. Great leaders who make the mix work. Harvard Business Review, 91(9): 68-76.

Hayes, A. F. 2013. Introduction to mediation, moderation, and conditional process analysis: A regression-based approach. New York: The Guilford Press.

He, L. Google's secrets of innovation: Empowering its employees. Forbes. Retrieved from http://www.forbes.com/sites/laurahe/2013/03/29/googles-secrets-of-innovation-empoweringits-employees/, March 29, 2013. 
Heathfield, S. M. Change management lessons about employee involvement: Employee involvement is key in change management. Retrieved from http://humanresources.about.com/od/changemanagement/a/change_lessons3.htm, October $18,2015$.

Aon Hewitt. How does change affect employee engagement? Retrieved from https://www.towerswatson.com/en-US/Insights/Newsletters/Global/SustainablyEngaged/2015/how-does-change-affect-employee-engagement, January, 2015.

Hughes, M. (2011). Do 70 per cent of all organizational change initiatives really fail? Journal of Change Management, 11(4): 451-464.

Jones, E., Chonko, L., Rangarajan, D. \& Roberts, J. (2007). The role of overload on job attitudes, turnover intentions, and salesperson performance. Journal of Business Research, 60(7): 663-671.

José, P.E. 2013. Doing statistical mediation and moderation. New York: The Guilford Press.

Judge, T. A., Bono, J. E., \& Locke, E. A. 2000. Personality and job satisfaction: The mediating role of job characteristics. Journal of Applied Psychology, 85(2): 237-249.

Kahn, R., Rehman, A. U. \& Fatima, A. 2009. Transformational leadership and organizational innovation: Moderated by organizational size. African Journal of Business Management, 3(11): 678-684.

Kane, S. The multigenerational workforce: Getting along with all generations, Generation Y. About careers. Retrieved from http://legalcareers.about.com/od/practicetips/a/GenerationY.htm, May 11, 2016.

Kanter, R. 2008. Transforming giants. Harvard Business Review, 86(1): 43-52.

Kase, L. 2010. Great leaders are great decision-makers. Graziadio Business Review, 13(4). Retrieved from http://gbr.pepperdine.edu/2010/10/great-leaders-are-great-decision-makers/

Kegan, R. \& Lahey, L. 2009. Immunity to change: How to overcome it and unlock the potential in yourself and your organization. Boston: Harvard Business Press.

Kenny, D. Mediation: Indirect effect. Retrieved from http://davidakenny.net/cm/mediate.htm, May 22, 2016.

Klenke, K. 2008. Qualitative research in the study of leadership, Bingley, UK: Emerald Group Publishing Limited.

Korunka, C., Kubicek, B., Schaufeli, W., \& Hoonakker, P. L. T. 2009. Work engagement and burnout: testing the robustness of the job demands-resources model. Journal of Positive Psychology, 4(3): 243-255. 
Kotter, J. 2001. What leaders really do? Harvard Business Review, 79(11): 85-96.

Kotter, J. \& Cohen, D. 2002. The heart of change: Real-life stories of how people change their organizations. Boston: Harvard Business School Publishing.

Kouzes, J. \& Posner, B. 2012. The leadership challenge: How to make extraordinary things happen in organizations, San Francisco: Jossey-Bass.

Leana, C. R., D. M. Rousseau, eds. 2000. Relational Wealth: The Advantages of Stability in a Changing Economy. Oxford University Press: Oxford, UK.

Lewis, L.K. 1999. Disseminating information and soliciting input during planned organizational change: Implementers' targets, sources, and channels for communicating. Management Communication Quarterly, 13(1): 43-75.

MacKinnon, D. P. 2008. Introduction to statistical mediation analysis. New York: Routledge.

Mallinger, M., Goodwin, D. \& O’Hara, T. 2009. Recognizing organizational culture in managing change. Graziadio Business Review, 12(1). Retrieved from http://gbr.pepperdine.edu/2010/08/recognizing-organizational-culture-in-managing-change/

Maslach, C., Jackson, S. E., \& Leiter, M. P. 1997. Maslach burnout inventory. In C. P. Zalaquett and R. J. Wood (Eds.) Evaluating stress: A book of resources, 3: 191-218.

Mauno, S., Kinnumen, U. \& Ruokolainen, M. 2007. Job demands and resources as antecedents of work engagement: A longitudinal study. Journal of Vocational Behavior, 70(1): 149-171.

McGrath, R. G. 15 years later, lessons from the failed AOL-Time Warner merger. Fortune. Retrieved from http://fortune.com/2015/01/10/15-years-later-lessons-from-the-failed-aoltime-warner-merger/ , January 10, 2015.

Mendes, F., \& Stander, M. W. 2011. Positive organisation: The role of leader behaviour in work engagement and retention. South African Journal of Industrial Psychology, 37(1): 29-41. 0

Meyer, C. Emotions versus feelings. Retrieved from http://emotionaldetective.typepad.com/emotional-detective/2012/04/emotions-vsfeelings.html, April 25, 2012.

Miller, F. A. 1998. Strategic culture change: The door to achieving high performance and inclusion. Public Personnel Management, 27(2): 151-160.

Mustafa, R., Shaikh, S. \& Haroon, A. 2012. Chaos and order are not enemies, only opposites: A case study of PICIC Bank. Business Management Dynamics, 1(8): 1-7. 
Nearly 70\% of Americans shop online regularly with close to $50 \%$ taking advantage of free shipping. Retrieved from http://www.mintel.com/press-centre/technology-presscentre/nearly-70-of-americans-shop-online-regularly-with-close-to-50-taking-advantage-offree-shipping, July 13, 2015.

Osterman, P. 2000. Work reorganization in an era of restructuring: Trends in diffusion and effects on employee welfare. Industrial and Labor Relations Review, 53(2): 179 - 196.

Pardey, D. 2007. Leadership in turbulent times. Strategic HR Review, 6(5): 16-19.

Persson, A. Identifying predictors of work engagement: An example from a management consultancy company. Retrieved from http://www.diva-portal.org/smash/get/diva2:323817/FULLTEXT01.pdf, 2010.

Pitt-Catsouphes, M. \& Matz-Costa, C. 2008. The multi-generational workforce: Workplace flexibility and engagement. Community, Work \& Family, 11(2): 215-229.

Porath, C. Half of employees don't feel respected by their bosses. Harvard Business Review. Retrieved from https://hbr.org/2014/11/half-of-employees-dont-feel-respected-by-theirbosses, November 19, 2014.

Preacher, K. J., \& Hayes, A. F. 2008. Asymptotic and resampling strategies for assessing and comparing indirect effects in multiple mediator models. Behavior research methods, 40(3): 879-891.

Rafferty, A. E., \& Simons, R. H. 2006. An examination of the antecedents of readiness for finetuning and corporate transformation changes. Journal of Business and Psychology, 20(3): 325-350.

Ravichandran, K., Arasu, R., \& Kumar, S. A. 2011. The impact of emotional intelligence on employee work engagement behavior: An empirical study. International Journal of Business and Management, 6(11): 157-169.

Resnicow K. \& Page, S. E. 2008. Embracing chaos and complexity: A quantum change for public health. American Journal of Public Health, 98(8): 1382-1389.

Salanova, M., Augut, S. \& Peiró, J. M. 2005. Linking organizational resources and work engagement to employee performance and customer loyalty: The mediation of service climate. Journal of Applied Psychology, 90(6): 1217-1227.

Salanova, M., Lorente, L., Chambel, M. J., \& Martínez, I. M. 2011. Linking transformational leadership to nurses' extra-role performance: the mediating role of self-efficacy and work engagement. Journal of Advanced Nursing, 67(10): 2256-2266.

Saldaña, J. (2013). The coding manual for qualitative researchers. Washington D. C.: Sage. 
Schaufeli, W. B., Bakker, A. \& Salanova, M. (2006). The measurement of work engagement with a short questionnaire, Educational and Psychological Measurement, 66(4): 701-716.

Schaufeli, W. B., Salanova, M., González-romá, V., \& Bakker, A. B. 2002. The measurement of engagement and burnout: A two sample confirmatory factor analytic approach. Journal of Happiness Studies, 3(1), 71-92.

Seppälä, P., Mauno, S., Feldt, T., Hakanen, J., Kinnunen, U., Tolvanen, A. \& Schaufeli, W. (2009). The construct validity of the Utrecht Work Engagement Scale: Multisample and longitudinal evidence. Journal of Happiness Studies, 10, 459-481.

Seyranian, V. 2014. Social identity framing communication strategies for mobilizing social change. The Leadership Quarterly, 25(3): 468-486.

Shamir, B., \& Kark, R. 2004. A single-item graphic scale for the measurement of organizational identification. Journal of Occupational and Organizational Psychology, 77(1): 115-123.

Simpson, M. R. (2008). Engagement at work: A review of the literature. International Journal of Nursing Studies, 46(7): 1012-1024.

Sinek, S. 2009. How great leaders inspire everyone to take action: Start with why. New York: Penguin Group.

Sirkin, H. L., Keenan, P. \& Jackson, A. (2005). The hard side of change management. Harvard Business Review, 83(10):108-18.

Skjei, S. 2014. Leaders' lived experience of authentic moments. In K. Schuyler, J. Baugher, K. Jironet \& L. Lid-Falkman (Eds.), Leading with spirit, presence, \& authenticity: 213-231. San Francisco: Jossey-Bass.

Smelzer, L.R. \& Zener, M.F. 1992. Development of a model for announcing major layoffs. Group and Organisation Management: An International Journal, 17(4): 446-472.

Strebel, P. 1996. Why do employees resist change? Harvard Business Review, 74(3): 86-92.

Tichy, N. \& Devanna, M. 1986. The transformational leader. New York: John Wiley \& Sons.

Uhl-Bien, M., Marion, R. \& McKelvey, B. 2007. Complexity leadership theory: Shifting leadership from the industrial age to the knowledge era. The Leadership Quarterly, 18(4): $298-318$.

Uma, S. 2013. A study on training importance for employees of their successful performance in the organization. International Journal of Science and Research, 2(11), 137-140. 
Van Quaquebeke, N., Kerschreiter, R., Buxton, A. E., \& van Dick, R. 2010. Two lighthouses to navigate: Effects of ideal and counter-ideal values on follower identification and satisfaction with their leaders. Journal of Business Ethics, 93(2): 293-305.

Vecina, M. L., Chacon, F., Sueiro, M., \& Barron, A. 2011. Volunteer engagement: Does engagement predict the degree of satisfaction among new volunteers and the commitment of those who have been active longer? Applied Psychology, 61(1): 130-148.

Vroom, V. H. 2000. Leadership and the decision-making process. Organizational Dynamics, 28(4): 82-94.

Weiner, B. J., Amick, H. \& Less, S. Y. 2008. Conceptualization and measurement of organizational readiness for change: A review of the literature in health services research and other fields. Medical Care Research Review, 65(4): 379 - 436.

Wharton, L. E. Order through chaos. Course and Direction. Retrieved from http://www.strategyletter.com/CD0804/guest_article.php, 2016.

Yalabik, Z. Y., Popaitoon, J. A. \& Rayton, B. A. 2013. Work engagement as a mediator between attitudes and outcomes. The International Journal of Human Resource Management, 24(14): 2799-2823.

Young, R. \& Hobson, J. What it's like to lead a non-hierarchical workplace. Here \& Now. Retrieved from http://hereandnow.wbur.org/2015/07/01/wl-gore-ceo-terri-kelly, July 1, 2015. 


\section{APPENDICES}

FIGURE 1

Direct/Indirect Relationships of Employee Perceived Aligned Change to Work Engagement

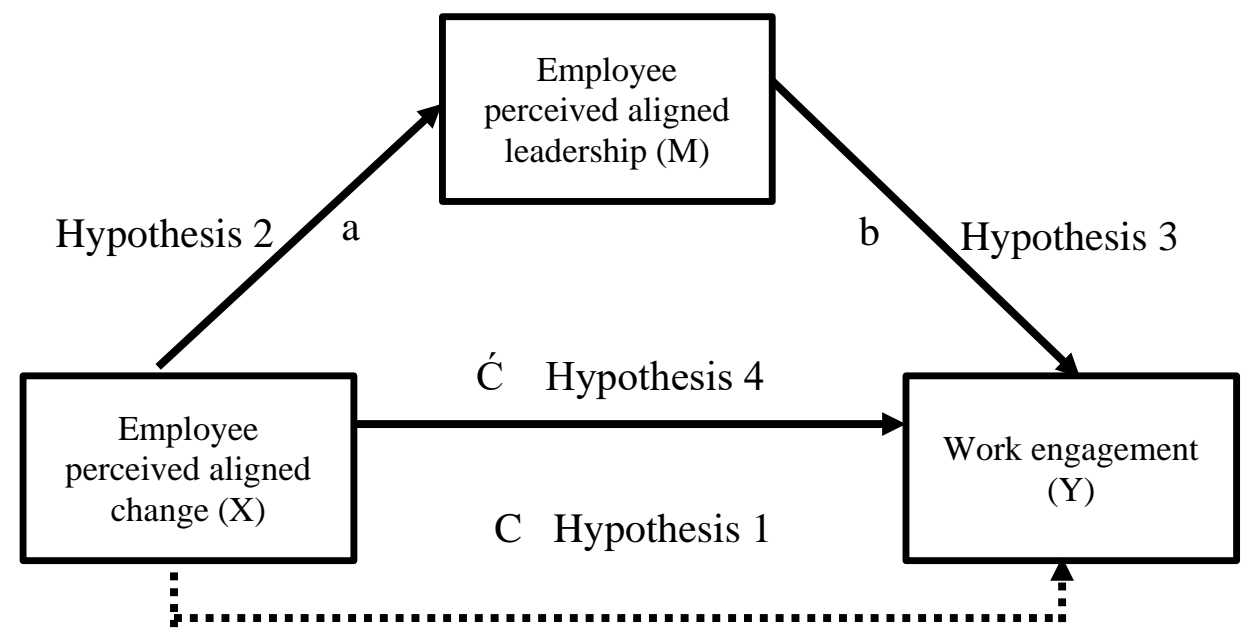

Note: Where: $\mathrm{X}=$ Predictor Variable; $\mathrm{M}=$ Mediator; $\mathrm{Y}=$ Outcome Variable; $\mathrm{a}=$ Direct Relationship between $\mathrm{X}$ and $\mathrm{M} ; \mathrm{b}=$ Direct Relationship between $\mathrm{M}$ and $\mathrm{Y} ; \mathrm{C}=$ Direct Relationship between $\mathrm{X}$ and $\mathrm{Y} ; \mathrm{C}=$ Indirect (Mediated) Relationship between $\mathrm{X}$ and $\mathrm{Y}$

FIGURE 2

Venn Diagram Scale: Alignment between Ideal Changes and Observed Changes

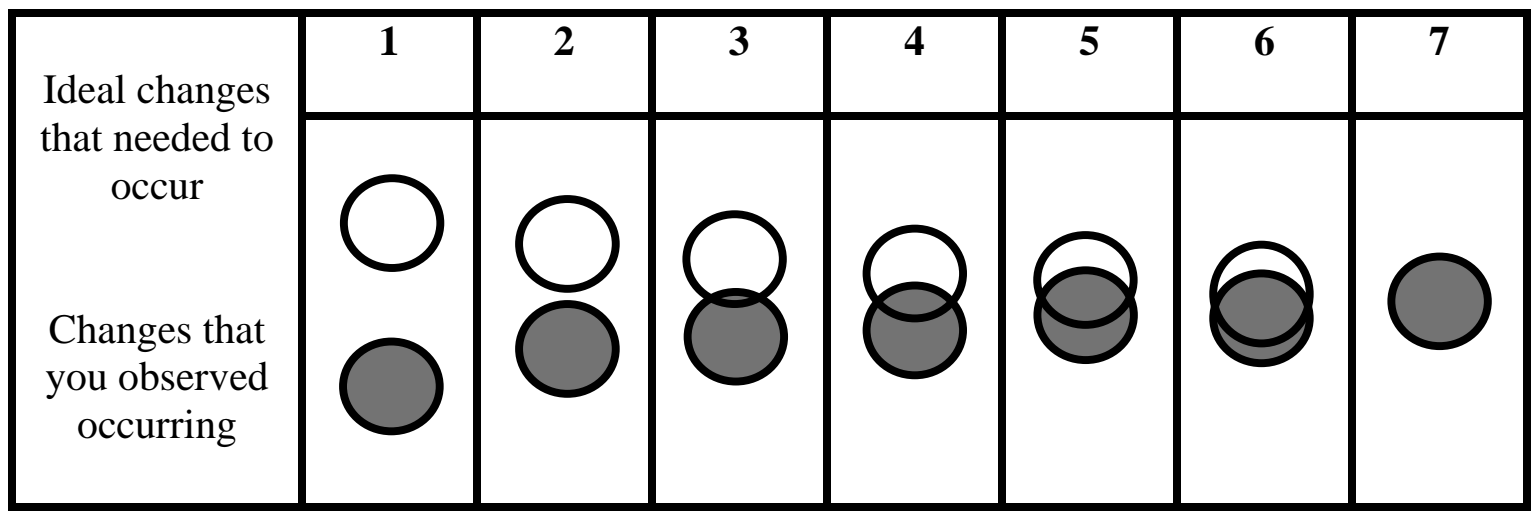


FIGURE 3

AMOS Fully Saturated Model Standardized Coefficients for the Mediation of Employee Perceived Aligned Leadership on Employee Perceived Aligned Change as related to Work Engagement

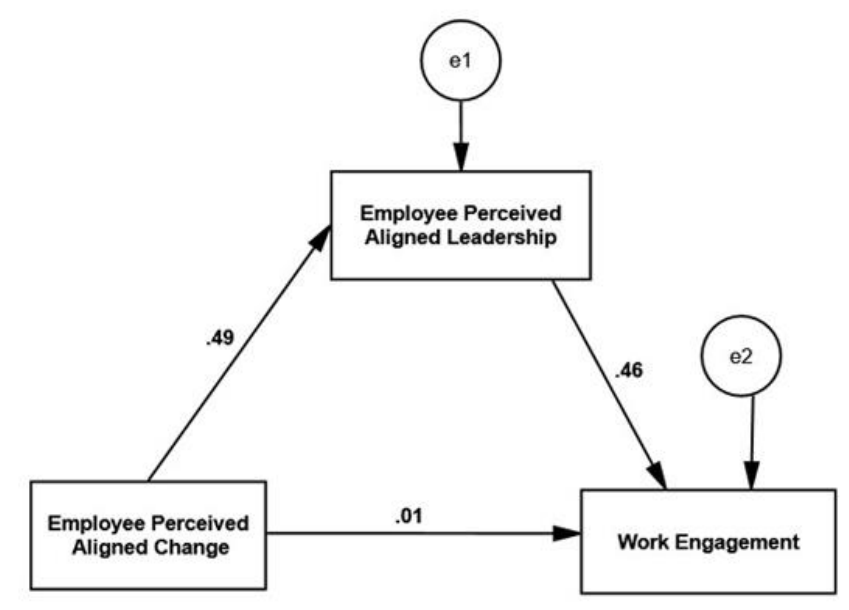

Note: Where Path $\mathrm{a}=.49 ;$ Path $\mathrm{b}=.46$ and Path $\mathrm{c}=.01$

\section{FIGURE 4}

AMOS Pruned Model Standardized Coefficients for the Mediation of Employee Perceived Aligned Leadership on Employee Perceived Aligned Change

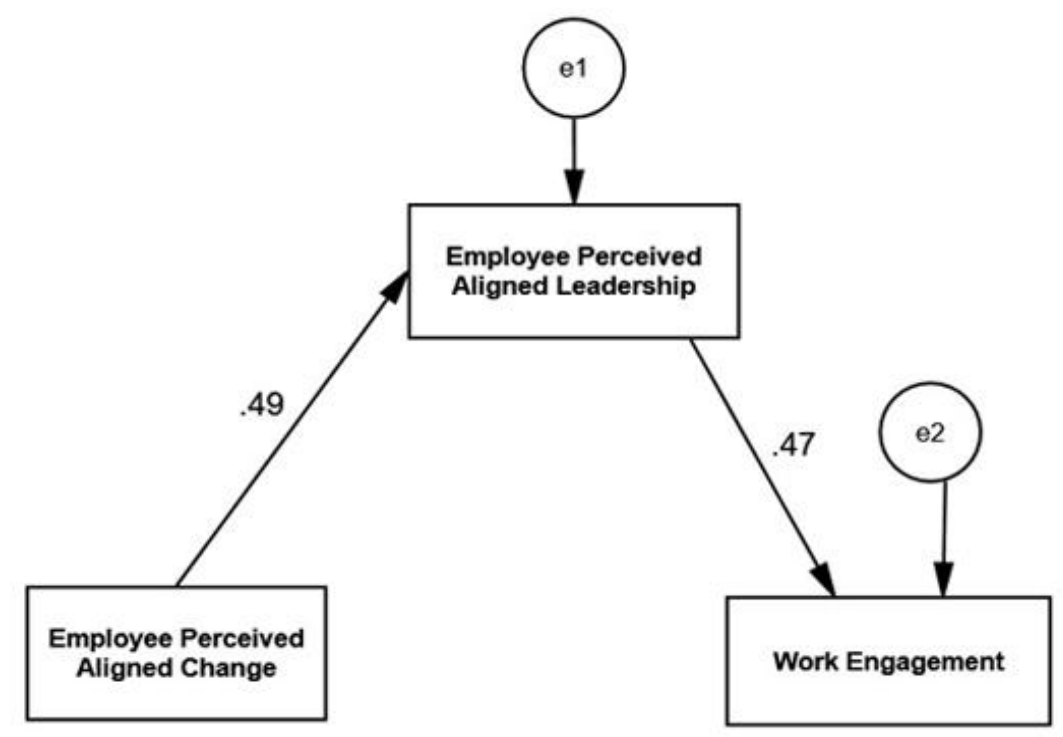

Note: Where Path $\mathrm{a}=.49$ and Path $\mathrm{b}=.47$ 
TABLE 1

Means, Standard Deviations and Correlation Matrix for Main Study Variables and Associated Covariates

\begin{tabular}{|c|c|c|c|c|c|c|c|c|c|c|}
\hline Variable & Mean & sd & 1 & 2 & 3 & 4 & 5 & 6 & 7 & 8 \\
\hline $\begin{array}{l}\text { 1. Employee } \\
\text { perceived aligned } \\
\text { change }\end{array}$ & 3.29 & 1.48 & - & & & & & & & \\
\hline $\begin{array}{l}\text { 2. Employee } \\
\text { perceived aligned } \\
\text { leadership }\end{array}$ & 3.48 & 1.71 & $0.49 * * *$ & & & & & & & \\
\hline $\begin{array}{l}\text { 3. Work } \\
\text { engagement }\end{array}$ & 3.75 & 0.93 & $0.24 * *$ & $0.47 * * *$ & & & & & & \\
\hline 4. Age category & 4.05 & 1.79 & 0.06 & -0.01 & 0.06 & & & & & \\
\hline 5. Gender & 1.62 & 0.49 & -0.01 & -0.01 & $-0.16^{*}$ & 0.09 & & & & \\
\hline 6. Education level & 3.30 & 1.10 & -0.13 & 0.01 & $-0.17 *$ & 0.11 & 0.05 & & & \\
\hline $\begin{array}{l}\text { 7. Months passed } \\
\text { since event }\end{array}$ & 9.30 & 6.83 & -0.04 & -0.02 & -0.04 & -0.02 & 0.04 & -.06 & & \\
\hline $\begin{array}{l}\text { 8.Organizational } \\
\text { layers between } \\
\text { change agent and } \\
\text { employee }\end{array}$ & 2.67 & 1.46 & 0.03 & -0.02 & $-0.21 *$ & -0.09 & $0.29 * *$ & $-.24 * *$ & .11 & \\
\hline $\begin{array}{l}\text { 9. No. employed } \\
\text { by category }\end{array}$ & 3.63 & 1.59 & $-0.18 *$ & $-0.23 *$ & $-0.17 *$ & -0.05 & $0.23 *$ & -.10 & $.26 *$ & $.41 * * *$ \\
\hline \multicolumn{11}{|l|}{ Note: $\mathrm{N}=105$} \\
\hline$* \quad p<.05$ & & & & & & & & & & \\
\hline$* * p<.01$ & & & & & & & & & & \\
\hline$* * p<.001$ & & & & & & & & & & \\
\hline
\end{tabular}


TABLE 2

Hierarchical Multiple Regression Predicting Work Engagement from Predictor Variables and Demographic and Organizational Covariates

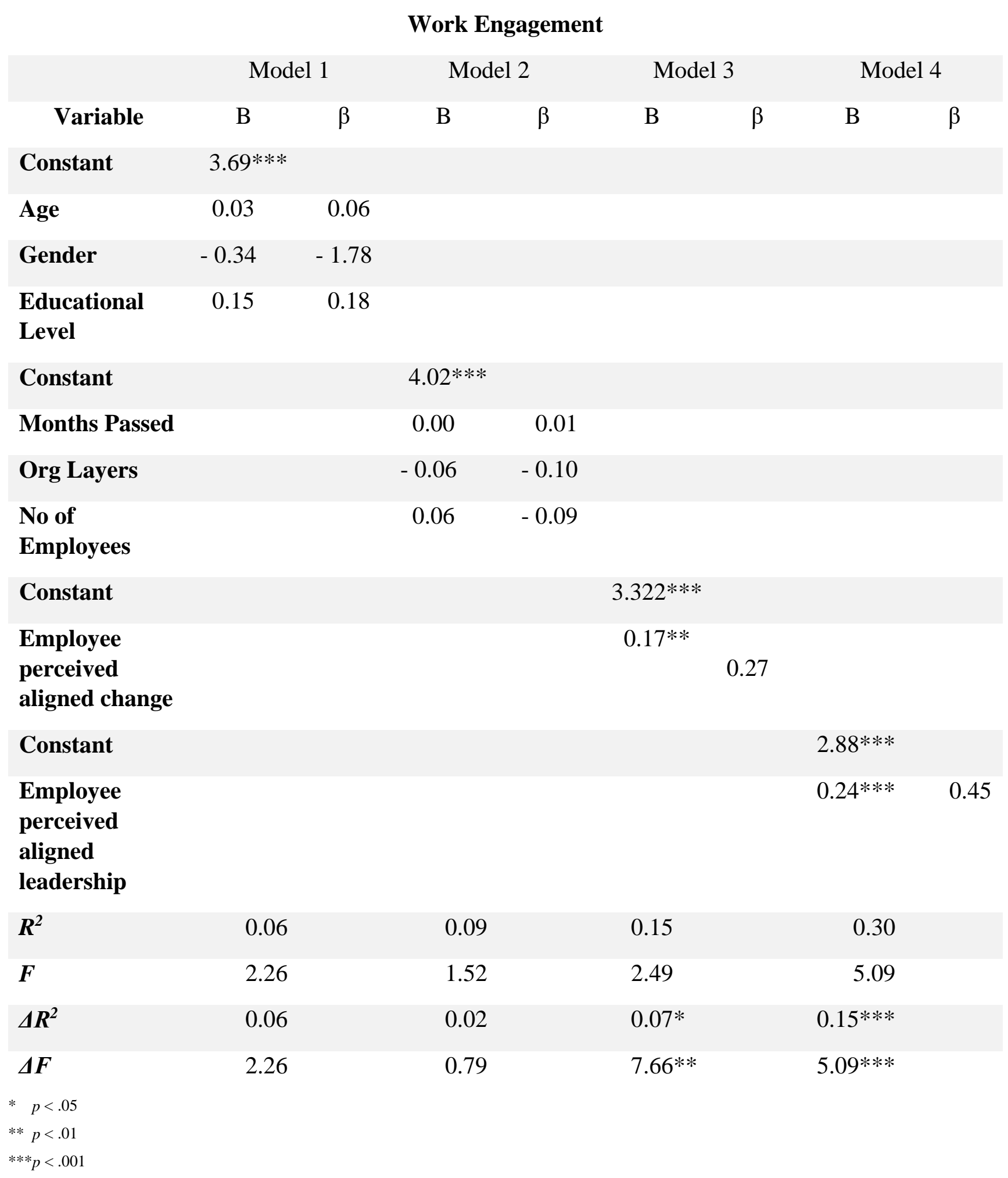

